\title{
Conservation of Plant Biodiversity: Current Strategies and Future Needs
}

\author{
Amanjot Kaur \\ Assistant Professor, Dep. of Botany, D.A.V. College, Amritsar -143006, India \\ *Corresponding author: amanjotdav@gmail.com
}

Available online at: www.isroset.org

Accepted: 12/Aug/2018, Online: 30/Aug/ 2018

\begin{abstract}
The issues related to the threats to plant biodiversity and its conservation have not been much highlighted as in the case of animal biodiversity. Out of seven million species of plants and animals living on the earth, there are nearly 3,90,800 plants species. Deforestation, habitat destruction, climate change, invasive species, pollution, mining, river valley projects, human overpopulation and over-harvesting are the major threats to plant biodiversity. This review focuses on effect of biodiversity loss on ecosystems, the need to conserve plant diversity and the present conservation strategies. It also highlights the biodiversity conventions around the world and measures to taken to protect plant diversity globally.
\end{abstract}

Keywords: Biodiversity, Deforestation, Invasive species, Conservation, Strategies.

\section{Introduction}

Biodiversity is the variety and variability among living organisms existing on earth from all sources including plants, animals and microorganisms in different ecosystems and ecological complexes. The concept of biodiversity was coined by Walter G. Rosen, from the National Research Council/National Academy of Sciences (NRC/NAS) in 1985[1]. Plants are important part of biodiversity. Plants not only fulfill living being's basic need of food but also are of economic and medicinal importance. For example traditional Chinese medicine alone uses more than five thousand plant species and ayurvedic medicines in India uses more than 7,000 different plant species. The planet Earth is losing biodiversity is at an unprecedented alarming rate. Deforestation, habitat destruction, climate change, invasive species, pollution, mining, river valley projects, human overpopulation and over-harvesting are the major threats to plant biodiversity [2]. The term "biodiversity conservation" means the attempts to conserve any parts of natural diversity. As plant diversity is a major part of biodiversity so plant conservation is an important essential component for biodiversity conservation. Although the species extinction is a continuous process and natural phenomenon but a considerable proportion of the biodiversity is endangered and many species have suffered anthropogenic extinctions. The current extinction episode, the "sixth extinction wave," may prove to be the most rapid and devastating [3]. According to The International Union for Conservation of Nature (IUCN) (which is membership Union uniquely composed of both government and civil society organizations to provide public, private and non- governmental organizations with the knowledge and tools that enable human progress, economic development and nature conservation to take place together) 784 extinctions have been recorded since the year 1500 with many more likely to have gone unnoticed. Science education is the pivot factor for an environmentally literate society. For many problems and challenges for next generation like conservation of ecosystem services, conservation of threatened species, climate change etc, the science education and in particular Botanical science plays a key role. But unfortunately there is a continuous decline in botanical curricula and number of students in universities and colleges. Wandersee et. al. explained a phenomenon called as plant blindness, which is the inability to see or notice the plants in one's own environment, the inability to recognize the importance of plants in the biosphere and in human affairs, inability to appreciate aesthetic and unique biological features of life forms that belong to Plant Kingdom[4]. The continuous decline in plant diversity has been hard to quantify. This is because of the fact that there are huge numbers of known and unknown species [5].

\section{Effect of biodiversity loss on ecosystems}

Biodiversity and ecosystem functioning is the latest field of research over last two decades. This field has begun to quantify how the world's biological diversity can, as an independent variable, control ecological processes and the functioning of ecosystems [6]. There are theoretical foundations and large enough data sets to quantify that biodiversity regulate several processes that are essential for the functioning of ecosystems. There is increasing concern 
of the consequences of biodiversity loss in ecosystem functioning. There should be some experimental evidence for a relationship between biodiversity and ecosystem process rates. Also Balvanera et. al. gave the first rigorous quantitative assessment of this relationship by analyzing 446 measures of biodiversity effects. The analysis showed that biodiversity effects are weaker if biodiversity manipulations are less well controlled [7]. Sandra Quijasa et. al. confirmed previously suggested positive effects of plant diversity on ecosystem services like erosion control, resistance to plant invasions and pathogen regulation. It was concluded from the experimental results that it is important to maintain plant diversity to ensure an increased provision of ecosystem services which benefit human well-being. Therefore, maintaining plant diversity is crucial if the management goal is to ensure benefits for human well-being [8]. Ecosystem processes, in general depend on the number of species and identity of the species in the ecosystem. Tilman [9] et al described three simple models of inter specific competitive interactions in communities containing various numbers of randomly chosen species. These models show that species identity and biodiversity simultaneously influence ecosystem functioning although their relative importance varies greatly among the models [9]. Anthropogenic global changes in biodiversity are generally portrayed in terms of massive native species losses or invasions caused by recent human disturbance [10]. Also biodiversity of many remote parts of the world is little known. Plants make a big taxonomic sample of biodiversity. Pimm et. al. suggested that there are 450,000 species, $2 / 3$ of these are in the tropic regions and $1 / 3$ of all species are at risk of extinction at a rate of 1000 to 10,000 times than the previous rate [11]. Each plant species has a limited range of tolerance to climatic variables. As anthropogenic climate changes, species must acclimatize, adapt, move or die. Corlett et. al. showed that movements by many plant species are likely to lag behind broad-scale patterns of climate change over the end of this century [12].

\section{Why to conserve plant biodiversity?}

\section{For Biological resources}

A biological resource is a substance or object that is required by an organism for normal growth, maintenance and reproduction. Also any object that is harvested from nature is the part of biological resources. These resources come under several categories such as paper, cosmetics and personal care products, medicine, food, wood products, fibers, genes for crop breeding, pest control, and recreation etc. [13].

\section{Ecosystem Services}

Ecosystem services are the benefits which human beings obtain from ecosystems. As these services are not obvious we generally take them for granted. These services are directly enjoyed, consumed, or used for well-being of humans. These services are end product of nature. These services for example are integral to the provisioning of clean drinking water, pollination, renewal of soil fertility, the decomposition of wastes etc [14]. There is interplay between the contemporary evolution and ecological changes and it determines the response of organisms and ecosystems to anthropogenic pressures. For example, on wild species include responses to harvest, habitat loss and fragmentation, biotic exchange and climate change [15]. The ecosystem services are critical to the proper functioning of the Earth's life-support system as either directly and indirectly, these services contribute to human welfare. So these services have reasonable share in the total economic value of the earth planet. The ecosystem services are often given very less importance in policy decisions as these services are not fully captured in commercial markets [16].For conserving species, there should be application of theoretical concepts into practical[17]. There is requirement of some active adaptive management and governance of resilience so as to sustain desired ecosystem states. Also there is urgent need to transform degraded ecosystems into fundamentally new and more desirable configurations [18].

\section{Option values}

Option values include the potentials of biodiversity which are currently unknown and need to be explored. For example, there is a possibility that within the depths of marine ecosystem or a tropical rainforests, there may have some potential cure of AIDS or cancer.

\section{Spiritual and Social Benefits}

Conservation of biodiversity also involves protecting nature for the spiritual gifts and protecting sacred places in the local landscape. Biodiversity provides a sense of place. In general, all Countries and states have flagship animals and plants which are source of their pride and uniqueness. Aesthetic and spiritual understandings of the value of nature lead people to develop moral responsibilities towards nature [19].

\section{Current Policies and Biodiversity}

Botanic Gardens Conservation International, BGCI is the world's largest plant conservation network helping to save the world's threatened plants. In 2010, the Conference of the Parties to the Convention on Biological Diversity (CBD) adopted an updated Global Strategy for Plant Conservation (GSPC). GSPC came into existence from the Convention on Biological Diversity and is being fed into government policy around the world. The GSPC highlights the importance of plants and the ecosystem services and aims to ensure their conservation. The major objective of GSPC is to provide education and awareness about plant diversity and its role in sustainable livelihoods, to understand, document and recognize plant diversity and to use diversity in a sustainable and equitable manner. Recently, a workshop was organized by the Secretariat of the Convention on Biological Diversity 
(CBD) in collaboration with Botanic Gardens Conservation International and Singapore Botanical Gardens, with financial support from Japan which focused on the need for and approaches towards reflecting national plant conservation targets established under the Global Strategy for Plant Conservation (GSPC) in national biodiversity strategies and action plans (NBSAPs). The workshop was held from 4-8 March. 2013 and included representatives from 11 countries in Southeast Asia (Cambodia, China, Indonesia, Lao People's Democratic Republic, Malaysia, Myanmar, Philippines, Singapore, Thailand, Timor Leste and Vietnam).The follow-up to the Global Strategy for Plant Conservation 2011-2020 will be considered in 2020 as part of the development of a post-2020 global biodiversity framework. In order to gather views on the nature and content of a Global Strategy for Plant Conservation beyond 2020 and how it might be integrated into the post-2020 global biodiversity framework, the CBD Secretariat has launched a survey - available in English and French. The results of the survey will be considered at the forthcoming Conference of the Global Partnership for Plant Conservation and the sixth meeting of the Liaison Group on the Global Strategy for Plant Conservation (Cape Town, South Africa 28-31 August 2018) [20]. Kayri Havens et. al. claimed that at present, no country is getting plant conservation right as a result of which plant species are becoming increasingly rare around the world. Generally the plants are not fully protected by any policy. Also the funds for their conservation are not adequate [21]. We are already too late to keep human influence away from Earth's biodiversity hotspots or anywhere else [22]. If far more vigorous conservation measures are not taken, the extinction of a sizeable number of plant species by the end of the century or shortly thereafter is sure [23].

\section{Biodiversity-related conventions}

\section{Convention on Biological Diversity}

The Convention on Biological Diversity (CBD) came into force on 29 December 1993 with prime objectives as the conservation of biological diversity, the sustainable use of the components of biological diversity and the fair and equitable sharing of the benefits arising out of the utilization of genetic resources.

\section{Convention on International Trade in Endangered Species of Wild Fauna and Flora (CITES)}

CITES is an international agreement between governments to ensure that international trade in specimens of wild animals and plants does not threaten their survival [24]. Today, it provides protection to more than 35,000 species of animals and plants irrespective of the fact that they are live specimens, fur coats or herbs in dried form. CITES came into existence in 1963 as a result of a resolution adopted at a meeting of members of IUCN. After that, the number of countries have ratified, approved, accepted or acceded to the
Convention. CITES has now 183 Parties with conservation agreements among them. Most recently, in 17th meeting held at Johannesburg in 2016, the Conference of the Parties adopted amendments to contribute to the achievement of the Agenda 2030 Sustainable Development Goals and their targets relevant to CITES [25]. On 26 July, 2018, the Parties, intergovernmental organizations, non-governmental organizations and industry representatives gathered in Geneva at the 24th meeting of the Plants Committee of the CITES. Ms. Adrianne Sinclair, the Chair of the Plants Committee, remarked that tree species now dominate the agenda of the Plants Committee. Further the Plants Committee sent a strong message to the CITES community regarding non-timber forest products.

\section{The International Treaty on Plant Genetic Resources for Food and Agriculture}

The objectives of the International Treaty on Plant Genetic Resources for Food and Agriculture are the conservation and sustainable use of plant genetic resources for food and agriculture and the fair and equitable sharing of the benefits arising out of their use, in harmony with the Convention on Biological Diversity, for sustainable agriculture and food security. Another important objective of the treaty is the sustainable use of plant genetic resources for food and agriculture [26]. This Treaty also recognizes the enormous contribution that the local and indigenous communities and farmers of all regions of the world have made for the conservation and development of plant genetic resources as it forms the basis of food and agriculture production around the world. Through the Multilateral System, the countries which adhere to the Treaty agreed to make their genetic diversity and related information about the crops stored in their gene banks available to all.

\section{Convention on Wetlands}

The Convention on Wetlands is also called the Ramsar Convention. It is an intergovernmental treaty which provides the framework for international cooperation for the conservation and wise use of wetlands and their resources [27]. The Ramsar Convention was adopted in 1971 in Ramsar (Iran). This convention came into action in 1975. Now approximately ninety percent of UN member states have agreed to become Parties of the convention. The Ramsar Convention is implemented by the Contracting Parties in their respective territories. The contracting Parties of the convention meet at the Conference after every three years in which the decisions to administer the Convention are adopted and implemented. It is one of the present multilateral environmental agreements which works in resonance with other relevant global treaties and it also has many agreements with non-governmental bodies.

\section{International Plant Protection Convention (IPPC)}

The International Plant Protection Convention (IPPC) is an international plant health agreement. The IPPC came into 
existence in April 1952. The IPPC Secretariat was established in 1992 at FAO headquarters in Rome. Its major objective is to protect cultivated and wild plants by preventing the introduction and spread of plant pests and suggesting the appropriate measures for their control[28]. IPPC helps to protect crops of farmers from economically devastating pests and disease. It also helps to save the environment from loss of species diversity and save ecosystems. IPPC works with Convention contracting parties at a global level. There are currently 183 contracting parties in the convention.

\section{Some recent advances around the world in plant diversity conservation}

1. Major Botanical Garden project initiated in the United Arab Emirates

Recently in July 2018, the Ruler of Sharjah Dr Sheikh Sultan Bin Mohammed Al Qasimi has signed a contract to establish the first phase of a new world class botanic garden in Sharjah. This garden will cover an area over 630,000 square metres. This project will mainly focus on conservation of the plant species and research. This botanic garden will have plant species from the UAE, Arabian Peninsula and other desert habitats that can be cultivated in its extreme desert locations.

\section{Baekdudagan National Arboretum}

Baekdudagan National Arboretum was opened for public in May 2018. Baekdudagan National Arboretum is located in the centre of Baekdudagan. It covers an area of 5,179 hectares. The major objective of Baekdudagan National Arboretum is to preserve native plants, rare plants, endemic plants and alpine plants of Korea by collecting and multiplying them. Baekdudagan National Arboretum has extensive facilities for latest scientific research such as Seed Vault, Seed bank and scientific laboratories.

\section{Conclusion}

The conservation of all plant species is important. For effective plant conservation, there should be right information about species distribution. Also, there should be information about the fact that where plant species occur and how rare that plants are. There should be proper research and training to protect threatened plant species. Further there should be a policy for funding. The protected areas should be well monitored with ex situ conservation in seed banks. Plants form a necessary support system for life on Earth. The decrease in plant diversity will be detrimental to all other groups of organisms including humans. There is an urgent need for all of us to work together to conserve plant diversity as the world cannot afford to lose a quarter of its plant species. The alterations to the planet's ecosystems due to human are so much intense and fast that biodiversity is becoming obsolete. Often human actions provoke fast evolutionary responses. Although there is widespread losses of native species due to invasions, domesticates and other intentional introductions, there is still the possibility to sustain most of Earth's plant species provided anthropogenic ecological succession can be redirected to sustain native plant species. This requires huge advances in scientific understanding of the process of conservation of native species within the novel plant communities which must be sustained by human systems across most of the terrestrial biosphere as it is virtually irreversible to conserve most species in native habitats.

\section{References}

[1] José Luiz de Andrade Franco, "The concept of biodiversity and the history of conservation biology: from wilderness preservation to biodiversity conservation" História vol.32 no.2 Franca July/Dec. 2013. http://dx.doi.org/10.1590/S0101-90742013000200003

[2] Suhas J. Vyas , Dipika Kara and Savan Tank "Eco-Physiological Study of Marshy and Sandy Habitats of Kachchh"International Journal of Scientific Research in Biological Sciences Vol.4, Issue.6, pp.1-7, December (2017)

[3] Gerardo Ceballos, Andrés García and Paul R. Ehrlich, "The Sixth Extinction Crisis :Loss of Animal Populations and Species", Journal of Cosmology, 2010, Vol 8, 1821-1831. JournalofCosmology.com, June, 2010

[4]Wandersee JH, EE Schussler, "Preventing plant blindness", Am Biol Teach 61:82-86,1999

[5] Brummitt, N.A., Bachman, S.P., Griffiths-Lee, , "Green plants in the red: A baseline global assessment for the IUCN Sampled Red List Index for plants", PLoS ONE 10(8): e0135152. doi:10.1371/journal.pone.0135152, 2015

[6] Cardinale B.J., "The functional role of producer diversity in ecosystems", Am J Bot. 2011 Mar;98(3):572-92. doi: 10.3732/ajb.1000364. Epub 2011 Mar 2

[7] Balvanera P, Pfisterer AB, Buchmann N, He JS, Nakashizuka T, Raffaelli D, Schmid B., "Quantifying the evidence for biodiversity effects on ecosystem functioning and services", Ecol Lett. 2006 Oct;9(10):1146-56.

[8] Sandra Quijasa, Bernhard Schmidb, Patricia Balvanera, "Plant diversity enhances provision of ecosystem services: A new synthesis", Basic and Applied Ecology,Volume 11, Issue 7, November 2010, Pages 582-593. https://doi.org/10.1016/j.baae.2010.06.009

[9] David Tilman, Clarence L. Lehman, Kendall T. Thomson, "Plant diversity and ecosystem productivity: Theoretical considerations", Proc Natl Acad Sci U S A 1997 Mar 4; 94(5): 1857-1861.

[10] Ellis, E.C., Antill, E.C., Kreft, H., (2012) "All is not loss: plant biodiversity in the Anthropocene", PLoS ONE 7(1): e30535. doi:10.1371/journal.pone.0030535

[11] Pimm, S.L., Joppa, L.N., 2015, "How many plant species are there, where are they, and at what rate are they going extinct?" Ann. Miss. Bot. Gard.100, 170-176

[12] Corlett, R.T., Westcott, D.A., 2013, "Will plant movements keep up with climate change?", Trends Ecol. Evol. 28, 482-488.

[13] Wanjui, "Biodiversity Conservation Needs and Method to Conserve the Biological Diversity", J Biodivers Endanger Species 2013, 1:3 DOI: 10.4172/2332-2543.1000113.

[14] Anna Hermann et. al. "The Concept of Ecosystem Services Regarding Landscape Research: A Review" Living Rev. Landscape Res.,5, (2011), 1. 
[15] Luis Santamari'a and Pablo F. Me'ndez, "Evolution in biodiversity policy - current gaps and future needs", Evolutionary Applications (2011)ISSN 1752-4571 doi:10.1111/j.17524571.2011.00229.x

[16] Costanza, R., R. D’arge, R. De Groot, S. Farber, M. Grasso, B. Hannon, K. Limburg et al. 1997. "The value of the world's ecosystem services and natural capital", Nature 387:253-260.

[17] Crandall, K. A., O. R. P. Bininda-Emonds, G. M. Mace, and R. K. Wayne. 2000, "Considering evolutionary processes in conservation biology. Trends in Ecology \& Evolution" 15:290295.

[18] Folke, C., S. Carpenter, B. Walker, M. Scheffer, T. Elmqvist, L. Gunderson, and C. S. Holling. 2004, "Regime shifts, resilience, and biodiversity in ecosystem management", Annual Review of Ecology, Evolution and Systematics 35:557-581.

[19] Nigel Cooper, E. Brady, Helen Steen, Rosalind Bryce ,"Aesthetic and spiritual values of ecosystems: Recognizing the ontological and axiological plurality of cultural ecosystem 'services', Ecosystem Services, Volume 21, Part B, October 2016, Pages 218-229.

[20] The Convention on International Trade in Endangered Species of Wild Fauna and Flora, Cites.org

[21] Kayri Havens, Andrea T. Kramer and Edward O. Guerrant Jr., "Getting Plant Conservation Right (Or Not): The Case Of The United States" , Int. J. Plant Sci. 175(1):3-10. 2014 DOI: $10.1086 / 674103$

[22] Ellis, E.C., Antill, E.C., Kreft, H., " All is not loss: plant biodiversity in the Anthropocene", PLoS ONE 7(1): e30535. doi:10.1371/journal.pone.0030535, 2012

[23] Myers N (1988), "Threatened biotas: 'hotspots' in tropical forests", Environmentalist 8:187-208

[24] Matthew J. Smith et. al., "Assessing the impacts of international trade on CITES-listed species: Current practices and opportunities for scientific research", Biological Conservation doi:10.1016/j.biocon.2010.10.018, 2010

[25] Conf. 16.3, CITES Strategic Vision: 2008-2020, The Conference Of The Parties To The Convention

[26] Rosie Cooney, "The Precautionary principle in biodiversity conservation and natural resource management: An issues paper for policy-makers, researchers and practitioners", IUCN Policy and Global Change Series No. 2

[27] Philippe Gerbeaux, "The Ramsar Convention: a review of wetlands management in New Zealand" Pacific Ecologist summer 2002/2003

[28] Bogdana Vujić , Filip Jovanović and Anđelka Mihajlov, "Mapping IPPC facilities in Vojvodina Province", The 6th PSUUNS International Conference on Engineering and Technology (ICET-2013), Novi Sad, Serbia, May 15-17, 2013 University of Novi Sad, Faculty of Technical Sciences

\section{Author Profile}

Ms. Amanjot Kaur pursued her
B.Sc(Medical) with Gold Medal from
H.M.V. College, Jalandhar and
M.Sc.(Botany) with Gold Medal from
G.N.D.U. Amritsar. She has teaching
experience of more than 13 years. She is
currently working as assistant Professor in Department of Botany, D.A.V. College Amritsar since 2004. Her area of specialization is Plant Taxonomy and ethno botany. 